\title{
REVIEW
}

\section{Social networking sites and older users - a systematic review}

\author{
Tobias Nef, 1,2,3 Raluca L. Ganea, ${ }^{1}$ René M. Müri1,2,4 and Urs P. Mosimann¹,2,5 \\ ${ }^{1}$ Gerontechnology and Rehabilitation Group, University of Bern, Bern, Switzerland \\ ${ }^{2}$ CCLM-Center for Cognition, Learning, and Memory, University of Bern, Bern, Switzerland \\ ${ }^{3}$ ARTORG Center for Biomedical Engineering Research, University of Bern, Bern, Switzerland \\ ${ }^{4}$ Division of Cognitive and Restorative Neurology, Department of Neurology, University Hospital Inselspital, University of Bern, Bern, Switzerland \\ ${ }^{5}$ Department of Old Age Psychiatry, University Hospital of Psychiatry, University of Bern, Bern, Switzerland
}

ABSTRACT

Background: Social networking sites can be beneficial for senior citizens to promote social participation and to enhance intergenerational communication. Particularly for older adults with impaired mobility, social networking sites can help them to connect with family members and other active social networking users. The aim of this systematic review is to give an overview of existing scientific literature on social networking in older users.

Methods: Computerized databases were searched and 105 articles were identified and screened using exclusion criteria. After exclusion of 87 articles, 18 articles were included, reviewed, classified, and the key findings were extracted. Common findings are identified and critically discussed and possible future research directions are outlined.

Results: The main benefit of using social networking sites for older adults is to enter in an intergenerational communication with younger family members (children and grandchildren) that is appreciated by both sides. Identified barriers are privacy concerns, technical difficulties and the fact that current Web design does not take the needs of older users into account.

Conclusions: Under the conditions that these problems are carefully addressed, social networking sites have the potential to support today's and tomorrow's communication between older and younger family members.

Key words: social media, social networking sites, older adults, Web 2.0, Facebook

\section{Introduction}

\section{Web 2.0 and social networking sites}

In the first generation of the World Wide Web (Web 1.0), Websites were largely limited to passive viewing of material created for them by site operators. Today, with the second-generation World Wide Web (Web 2.0), the Internet has evolved from one-way communication to a communication platform that enables interactive user involvement (Chou et al., 2010). There are many Websites with content entirely provided by users and where the operators simply deliver the framework and infrastructure that enables users to edit, modify, and link the content (e.g. Wikipedia and Yahoo! Answers). The Web 2.0 serves as a platform for information sharing, social interaction,

Correspondence should be addressed to: Urs P. Mosimann, M.D., Ph.D., Professor for Old Age Psychiatry, University Hospital of Psychiatry, Gerontechnology and Rehabilitation Group, University of Bern, Murtenstrasse 21, 3010 Bern, Switzerland. Phone: +41 3163288 17; Fax: +41 3163289 44. Email: urs.mosimann@gef.be.ch. Received 7 Nov 2012; revision requested 12 Dec 2012; revised version received 26 Feb 2013; accepted 26 Feb 2013. First published online 4 April 2013. and collaboration. A Web 2.0 site enables users to interact and collaborate with one another in a social dialogue as creators of user-generated content in a virtual community. Examples of Web 2.0 sites include social networking sites (SNS), blogs (discussion or information sites), wikis (that enable users to add, modify, or delete content), video sharing sites, and Web applications (i.e. applications that are accessed over the Internet).

This paper focuses on SNS (also known as "social media"), Web-based services that enable individuals to construct a public or semi-public profile within a bounded system, articulate a list of other users with whom they share a connection, and view and traverse their list of connections and those made by others within the system (Ellison, 2007). Examples of SNS include Facebook, MySpace, Google+, and Xing. Farkas (2010) presents an exhaustive list of SNS sites.

\section{Use of social networking sites}

From 2005 to 2009, SNS participation more than quadrupled (Jones et al., 2009). Today, social 
networking accounts for about $22 \%$ of all time spent online (Wire, 2010). Emblematic of this trend is the number of active Facebook users, which has reached 1 billion as of October 2012 (Facebook Inc.). Among these, 30\% are younger than 25 years, $41 \%$ are $26-44$ years old, $12 \%$ are $45-54$ years old, and $7 \%$ are older than 55 years (Johnson, 2012). The fastest-growing group is people over 50 years and the number of older SNS users is expected to grow significantly in the next years (Lovett, 2011).

The most prominent functions of SNS sites are communication and picture sharing (Joinson, 2008). For that purpose, each SNS member has a virtual wall where one can post messages and photos that are visible to friends within the SNS. Accepted SNS friends can look at the messages and photos and add comments. Depending on computer skills and preferences, this can be done using a personal computer, a tablet computer, or a mobile phone. Moreover, it is also possible to display SNS pictures automatically via a wall-mounted electronic picture frame. This has the advantage that it does not require computer know-how (Cornejo et al., 2010). The SNS dialogue is not public and only visible to a limited number of selected friends. Several researchers believe that SNS dialogues can be a way to reduce social isolation, loneliness, and promote involvement of older people in their family life (Farkas, 2010). Particularly for senior citizens with limited mobility, SNS may help them to maintain and underpin existing contacts and connections (Erickson, 2011). Also, using SNS might be a good mean of communication to help keeping up with what is going on in the lives of family members who are active on SNS. According to Giles et al. (2010), a growing body of literature in the USA and other Anglophone settings has focused on the dynamics of communication in intergenerational relations (Williams and Nussbaum, 2001; Nussbaum and Coupland, 2004; Harwood, 2007). Recently, several authors have speculated about the possible role of SNS to facilitate intergenerational communication for the benefit of both generations (Fees and Bradshaw, 2003; Williams et al., 2005; Mesch, 2012). More generally, there are growing numbers of scientific publications presenting new ideas and new methodologies on how SNS use can improve quality of life for older adults. Since the main purpose of SNS is communication, there is good reason to expect that SNS use will have a positive impact, both in terms of its users' social integration in a network of family, friends, and community and the benefits that flow from this integration (Shklovski et al., 2004). The diversity and the dosage of different communication methods (i.e. face-to-face meetings, telephone, and SNS) seems important - and bearing this in mind, there is controversy in the research literature about whether the use of the Internet and SNS increases or decreases users' social participation and the psychological and health benefits people generally receive from this participation (Shklovski et al., 2004). Some optimistic reports claim that using the Internet leads to the emergence of a new social circle (Turkle, 1997; Kraut et al., 2002) and the development of deep and longlasting social relationships online (McKenna et al., 2002), and that it augments involvement in existing communities by providing new social spaces for communication (Katz and Aspden, 1997; Wellman et al., 2001). In contrast, other analyses suggest that frequent Internet and SNS use was associated with increases in depression and social isolation (Kraut et al., 1998; McKenna et al., 2002) and declines in spending time with family and friends and in attending social events (Nie et al., 2002). These findings are from investigations in younger cohorts and cannot be transferred one-to-one to older SNS users. Therefore, positive and negative impacts of SNS use on mental health in older people need to be considered and further investigated.

In this paper, we review, classify, and summarize existing scientific literature. We also discuss possible negative and positive impacts of SNS use on mental health and, finally, we present possible future research directions.

\section{Methodology}

We conducted a systematic review of studies on Web 2.0 and social media for older adults published or in press (e-pub) prior to July 2012. To identify relevant studies, we searched computerized databases (Pubmed, PsycInfo, PsycArticles, IEEE Explore, ISI Web of Knowledge, Wiley Online Library, www.icahdq.org, and Google Scholar) using combinations of the following keywords for the population: aging, aged, ageing, elderly, elderlies, old, older adults, oldest-to old, seniors (Kueider et al., 2012). For the content search, we used social media, social platform, social networking sites, and Web 2.0 as title keywords. Drawing on the PRISMA recommendation for systematic reviews (Moher et al., 2009), we identified studies from reference lists in retrieved articles, unpublished dissertations, and conference abstracts.

To be included in the present review, an article (original peer-reviewed article, review and current opinion, conference proceedings, conference abstract, dissertation, or technical report) needed to contain the selected keywords, and could not meet any of the seven exclusion criteria which are (A) not specifically dealing with 


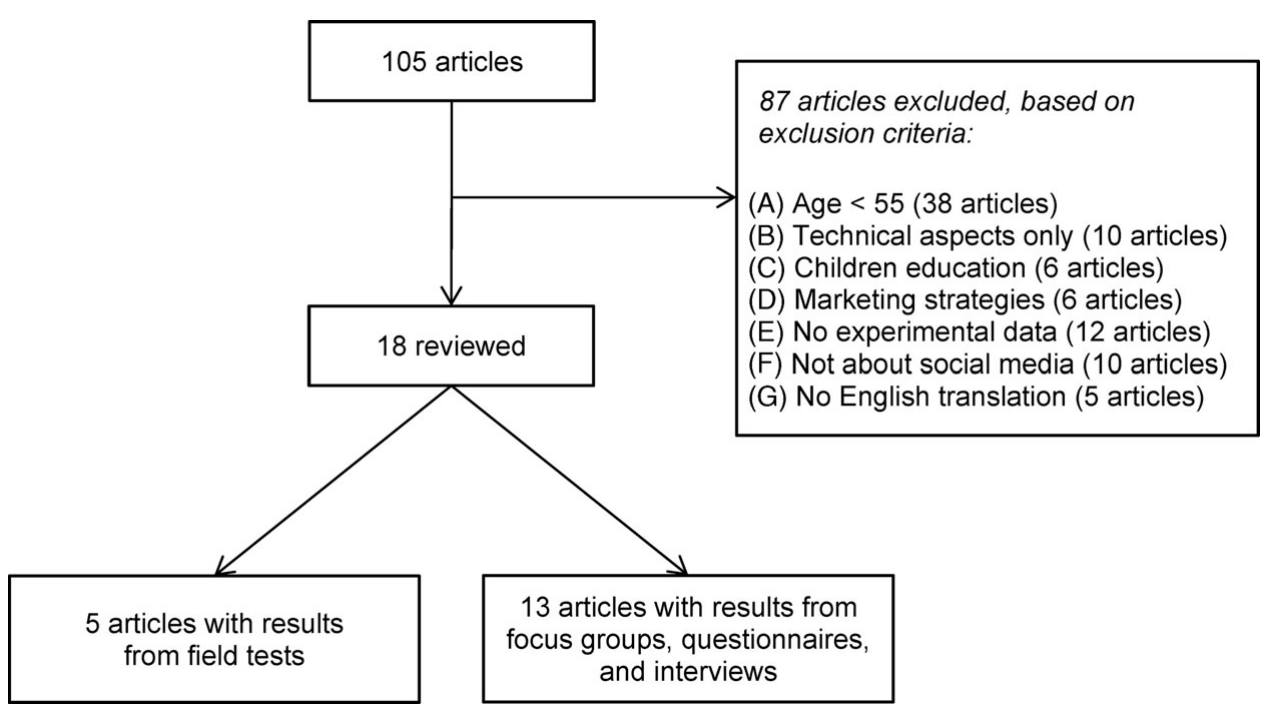

Figure 1. Identification of studies in the systematic review.

social media and people aged $\geq 55$ years; (B) focusing primarily on programming and technical aspects; (C) papers about children education; (D) marketing strategies for companies; (E) studies without interventions, interviews, or focus groups; (F) not about social media; and $(\mathrm{G})$ no English translation available.

Defining "old" is difficult and age classification varies among countries and over time (Seeman et al., 2001). As a working definition for this review and for exclusion criterion $A$, the chronological age of $\geq 55$ years was used. The authors feel that 65 years might be more appropriate, but several articles use $\geq 55$ years to characterize old (Lehtinen et al., 2009; Karimi and Neustaedter, 2010; Chou et al., 2012), so we adopted this artificial definition. The screening of the articles with regard to the exclusion criteria was performed independently by two authors. Non-conformities were discussed among all authors and a common inclusion/exclusion decision was made. After inclusion, the articles were classified into articles reporting results from a field test and articles that report results from user groups, interviews, and online surveys.

\section{Results}

\section{Articles included into the review}

Our initial search returned a total of 111 articles (22 Pubmed, 28 ISI Web of Knowledge, 23 IEEE Explore, 6 Wiley Online Library, 6 www.icahdq.org, and 26 Google Scholar). Six publications appeared in two databases and the duplicates were deleted. Thus, 105 publications were screened for inclusion. Two authors screened the articles independently ( $\mathrm{TN}$ and RG). Both authors excluded the same 79 articles, while
10 articles were excluded by one author only. After discussing each of the ten non-concurrent articles, all authors consensually agreed to exclude eight and to include two articles. Hence, 87 articles were excluded due to the following criteria: (A) not specifically dealing with social media and people aged $\geq 55$ years (38 articles), (B) focusing primarily on programming and technical aspects (ten articles), (C) papers about children education (six articles), (D) marketing strategies for companies (six articles), (E) studies without interventions, interviews, or focus groups (12 articles), (F) not about social media (ten articles), and $(G)$ no English translation available (five articles) (Figure 1).

\section{Articles reporting field tests of social networking sites with senior citizens}

Five articles report results from field tests (Table 1): two journal publications (JP), two conference proceedings (CP), and one dissertation (Diss). One $\mathrm{CP}$ describes the user-centered development of a desktop-computer independent user-interface to Facebook (Cornejo et al., 2010). The new interface consists of a wall-mounted electronic picture frame where SNS dialogues with photos are displayed. The advantage of this setup is that it does not require any computer skills. It allows the user to stay in touch with family members via SNS and to watch novel photographs in his or her home. The new interface has been tested for 21 weeks within the family of an 88-year-old lady without cognitive impairment. The test participant felt more involved with what is going on among family members and the acceptance of the new system was very high.

One publication (Chou et al., 2012) reported results from questionnaires $(\mathrm{N}=60)$ and observations 
Table 1. Articles with results from field tests

\begin{tabular}{|c|c|c|c|c|}
\hline AUTHOR & TYPE & POPULATION & METHOD & MAIN FINDINGS \\
\hline $\begin{array}{l}\text { Lehtinen } \\
\quad \text { et al. (2009) }\end{array}$ & JP & $\begin{array}{l}\mathrm{N}=8 \\
58-66 \text { years } \\
\text { (Internet users) }\end{array}$ & $\begin{array}{l}\text { Intervention study wherein } \\
\text { participants used an existing } \\
\text { SNS (Netlog). Group and } \\
\text { personal interviews were } \\
\text { also conducted. }\end{array}$ & $\begin{array}{l}\text { The test persons did not regularly use the } \\
\text { SNS. The most hindering factors were: } \\
\text { - Lack of confidence in computer skills } \\
\text { combined with concern about malicious } \\
\text { third parties using their personal } \\
\text { information. } \\
\text { - Fear of social blunders. } \\
\text { - Incompatibility of their perceptions of } \\
\text { social relationships with the perceptions } \\
\text { and assumptions about SNS. }\end{array}$ \\
\hline $\begin{array}{l}\text { Tsai and Chang } \\
\text { (2009); } \\
\text { Tsai et al. } \\
\text { (2011) }\end{array}$ & $\mathrm{CP}$ & $\begin{array}{l}\mathrm{N}=52 \\
64-91 \text { years }\end{array}$ & $\begin{array}{l}\text { A new touchscreen-based } \\
\text { interface for communication } \\
\text { with SNS has been } \\
\text { implemented and tested }\end{array}$ & $\begin{array}{l}\text { The vast majority of test participants } \\
\text { accepted the new touchscreen-based } \\
\text { interface for communicating with SNS } \\
\text { very well. }\end{array}$ \\
\hline
\end{tabular}

with older people. The technology acceptance model (TAM) was used to measure acceptance.

$\begin{array}{cll}\begin{array}{c}\text { Cornejo et al. } \\ \text { (2010) }\end{array} & \mathrm{CP} \quad \mathrm{N}=15 \\ & 65-97 \text { years } \\ & \text { (Focus groups) } \\ & \mathrm{N}=1 \\ & 88 \text { years } \\ & \text { (Experiment) }\end{array}$

Focus groups to investigate SNS requirements for older users.

Two technical systems for integration of older adults into Facebook were developed:

- A digital frame that collects and shows new photographs that are shared by family members via their Facebook account.

- Instrumented eBowls that allow an older adult to communicate its status (Ambient display).

Teixeira (2011) Diss $\quad \begin{aligned} & \mathrm{N}=10 \\ & 61-89 \text { years }\end{aligned}$

A touchscreen-based graphical user interface (GUI) has been developed that enables older adults to send SMSs and email, and share calendar data. The usability was tested in ten older adults.

\begin{tabular}{|c|c|c|c|c|}
\hline $\begin{array}{l}\text { Chou et al. } \\
\text { (2012) }\end{array}$ & JP & $\begin{array}{l}\mathrm{N}=60 \\
>55 \text { years } \\
\text { (Students of } \\
\text { computer } \\
\text { classes for } \\
\text { senior citizens) }\end{array}$ & $\begin{array}{l}\text { Questionnaires }(\mathrm{N}=60) \text { and } \\
\text { observation of older adults } \\
\text { using Facebook pages }(\mathrm{N}= \\
\text { 5). Five participants were } \\
\text { observed using the think } \\
\text { aloud approach. They were } \\
\text { asked to speak during the } \\
\text { process of using the SNS. } \\
\text { Their verbal data and } \\
\text { operation behavior were } \\
\text { recorded. }\end{array}$ & $\begin{array}{l}\text { Priorities of user requirements: } \\
\text { - Extreme protection of personal privacy. } \\
\text { - Ability to immediately find functional } \\
\text { buttons. } \\
\text { - More conveniently use the keyboard and } \\
\text { the mouse. } \\
\text { - Provide clear layout. } \\
\text { Priorities of technical requirements: } \\
\text { - Simple, clear, and consistent layout. } \\
\text { - Hyperlinks placed among bullets instead } \\
\text { of dense, linear arrangement. } \\
\text { - Fewer choices offered to enable users to } \\
\text { identify usage. }\end{array}$ \\
\hline
\end{tabular}

ested during 21 weeks ( $N=1,88$ years). The authors concluded that using SNS outside the desktop environment could help the user to maintain relationships with relatives. The person felt more involved in what's going on and the eBowl provided an easy means to communicate its status through the manipulation of physical objects.

The prototype GUI was considered adequate by the older adults, described as simpler, more natural, and more enjoyable than current GUIs.

$\mathrm{CP}=$ conference proceedings; Diss = dissertation; JP = journal publication; $\mathrm{N}=$ number of participants; SNS = social networking sites. 
$(\mathrm{N}=5)$ of older people using Facebook. For the observations, a "think aloud" approach was used. Users were asked to speak during the process of using the SNS. Their verbal comments and operation behavior were recorded and analyzed. The authors transformed those findings into recommendations for simplifying SNS use for senior citizens, including protection of personal privacy, improving keyboard/mouse use (e.g. problems with double-clicks), and providing a clearer layout. Prior technical requirements include hyperlinks not linearly arranged, fewer choices, and less text. Less text seems to be important since the authors observed that older users, in contrast to younger users, read everything displayed on the screen.

Lehtinen and colleagues (2009) observed eight Internet users (58-66 years old) who were about to start using an SNS. They found that test participants did not regularly use the SNS because of privacy concerns and because they did not see the benefit. The dissertation with the title "Improving elderly access to audiovisual and social media, using a multimodal human-computer interface," describes the development and evaluation of a new touchscreen-based graphical user interface (GUI) for older adults (Teixeira, 2011). While their proposed GUI resembles tablet-style interfaces, the interface proposed by Tsai and Chang (2009) tries to attract user attention by providing an aesthetic, artistic image to emotionally attract the users and encourage participation with the SNS. Tests of 52 older users revealed high acceptance rates.

\section{Articles assessing attitudes of senior citizens toward social networking sites}

Four journal publications (JP), eight conference proceedings (CP), and one technical report (TR) were identified. Six articles reported results from focus groups with older people (Table 2). Gibson and colleagues (2010) conducted two focus groups $(\mathrm{N}=17)$, interviews, and demonstrations with 6386 -year-old people. The main finding was that the purpose of SNS was difficult for older participants to grasp. Also, the authors highlighted that SNS aroused privacy concerns. According to the authors, this might be the main inhibitor for SNS use by older citizens. Privacy concerns and lack of trust are also reported as a result of focus groups conducted by Norval (2012) in eight older persons. Also, this population did not see the purpose or how such a site would benefit them in any way. In weekly, semi-structured, open-ended discussions with ten older persons, Xie et al. (2012) tried to answer the following questions: What are older adults' perceptions of SNS? What educational strategies can facilitate their learning of SNS? The authors illustrated changing perceptions from the initial unanimous, strong negative to the more positive but cautious, and to the eventual willingness to actually contribute content. Also, in this paper, privacy concerns were identified as a major issue. Focus groups with technically savvy older adults conducted by Nervik et al. (2011) revealed that focus group participants combine multiple communication channels, such as email, SMS, SNS, and Skype. Eggermont and Vandebosch (2009) used theater play to facilitate discussion in focus groups with 537 older persons. The findings are mixed; on the one hand, older people would like to see SNS to support social relationships and help them to overcome loneliness. On the other hand, participants strongly plead for the maintenance of face-to-face contacts. This differentiated view was also discovered in focus groups that were conducted in 83 older non-users of computers in New Zealand. Participants critically evaluated the new technology in terms of their own lives and in relation to their individual perceptions of technology's place in society (Richardson et al., 2007).

Seven articles used questionnaires and interviews to learn why older people use or do not use SNS. In telephone interviews with individuals older than 65 who use Facebook at least weekly, Erickson (2011) found that the main benefit of Facebook was about knowing what was going on among family members. Privacy issues and inappropriate content were the main concerns. In semi-structured interviews on technology and social media use, Karimi and Neustädter (2010) reported large variability in communication behavior and SNS use. To deal with this variability, the authors propose four archetypes: the living newspaper that maintains communication by relying on new technology; the high-tech social hub that is always online; the freespirited bird that maintains spontaneous lifestyle and interaction; and the isolated communicator who takes a large amount of effort to maintain communication, but these efforts are not always reciprocated. In telephone interviews, a US-national panel survey interviewed 3,500 persons of all age groups (Shklovski et al., 2004). The authors aimed to examine the influence of Internet and SNS use on communication and social involvement. The study analyzes cross-sectional and longitudinal (from follow-up interviews) data which led to different results. The longitudinal data indicate that heavy Internet use is associated with reductions in the likelihood of visiting family or friends on a randomly selected day. The cross-sectional data show that communication in one medium stimulates the others. In another online survey of 440 senior citizens, the authors also found that the usage of SNS and social contacts are supplementary, and 
Table 2. User groups, interviews, and online surveys

\begin{tabular}{|c|c|c|c|c|}
\hline AUTHOR & TYPE & POPULATION & METHOD & MAIN FINDINGS \\
\hline \multicolumn{5}{|c|}{ Studies using focus groups } \\
\hline $\begin{array}{l}\text { Richardson } \\
\text { et al. }(2007)\end{array}$ & $\mathrm{CP}$ & $\begin{array}{c}\mathrm{N}=83 \\
55-90 \text { years }\end{array}$ & $\begin{array}{l}\text { Focus groups with older } \\
\text { non-users of computers in } \\
\text { New Zealand. Seventeen } \\
\text { focus groups, ranging in size } \\
\text { from } 4 \text { to } 13 \text { participants } \\
\text { and each lasting between } 60 \\
\text { and } 90 \text { minutes, explored } \\
\text { participants' perceptions of } \\
\text { and stories about } \\
\text { computers. }\end{array}$ & $\begin{array}{l}\text { Participants' characterizations of } \\
\text { computers, as represented in the themes, } \\
\text { were developed in relation to a repertoire } \\
\text { of narrative resources acquired over a } \\
\text { lifetime. Drawing on this set of resources, } \\
\text { participants critically evaluated the } \\
\text { technology in terms of their own lives } \\
\text { and in relation to their perceptions of } \\
\text { technology's place in society. }\end{array}$ \\
\hline $\begin{array}{l}\text { Eggermont } \\
\text { et al. (2009) }\end{array}$ & $\mathrm{CP}$ & $\begin{array}{l}\mathrm{N}=537 \\
50-75 \text { years }\end{array}$ & $\begin{array}{l}\text { Focus group meetings, theater } \\
\text { play of four scenarios with } \\
\text { different levels of } \\
\text { technological involvement } \\
\text { and questionnaires. }\end{array}$ & $\begin{array}{l}\text { The findings are mixed, on the one hand, } \\
\text { older people would like to see SNS to } \\
\text { support the social relationships of older } \\
\text { adults and help them fight loneliness. } \\
\text { Also, technology may ameliorate their } \\
\text { physical condition and help them live } \\
\text { independently, offer them the } \\
\text { possibilities to stay mobile, to relax, to } \\
\text { learn, and to work, in other words, to } \\
\text { fully participate in society. On the other } \\
\text { hand, older adults strongly plead for the } \\
\text { maintenance of non-mediated } \\
\text { communication (face-to-face contacts), } \\
\text { and for non-technological alternatives in } \\
\text { the future. }\end{array}$ \\
\hline $\begin{array}{l}\text { Gibson et al. } \\
\text { (2010) }\end{array}$ & $\mathrm{CP}$ & $\begin{array}{l}\mathrm{N}=17 \\
63-86 \text { years }\end{array}$ & $\begin{array}{l}\text { Two focus groups }(\mathrm{N}=17) \\
\text { were conducted to study } \\
\text { older adults' thoughts and } \\
\text { feelings toward SNS. } \\
\text { Besides the focus groups, } \\
\text { ethnographic interviews (N } \\
=4) \text { and demonstrations }(\mathrm{N} \\
=15) \text { were also conducted. }\end{array}$ & $\begin{array}{l}\text { - Adverse media stories on SNS have a } \\
\text { major negative impact on participants. } \\
\text { - The purpose of SNS was difficult to } \\
\text { understand for older participants. } \\
\text { - SNS aroused privacy concerns }\end{array}$ \\
\hline $\begin{array}{l}\text { Nervik et al. } \\
\quad \text { (2011) }\end{array}$ & CP & $\begin{array}{l}N=5 \\
60-82 \text { years }\end{array}$ & $\begin{array}{l}\text { A focus group with technically } \\
\text { savvy older adults was } \\
\text { conducted. }\end{array}$ & $\begin{array}{l}\text { All participants stated that they are } \\
\text { frequent users of multiple } \\
\text { communication channels, such as email, } \\
\text { SMS, Facebook, and Skype. }\end{array}$ \\
\hline Norval (2012) & $\mathrm{CP}$ & $\begin{array}{l}\mathrm{N}=8 \\
>60 \text { years }\end{array}$ & $\begin{array}{l}\text { Two focus groups analyzed } \\
\text { the reasons for the low } \\
\text { uptake of SNS by older } \\
\text { adults. }\end{array}$ & $\begin{array}{l}\text { Caution toward an unmoderated site with } \\
\text { social functionality. Privacy concerns and } \\
\text { a lack of trust. Participants did not } \\
\text { understand the purpose or how such a } \\
\text { site would benefit them in any way. }\end{array}$ \\
\hline Xie et al. (2012) & JP & $\begin{array}{l}\mathrm{N}=10 \\
61-83 \text { years }\end{array}$ & $\begin{array}{l}\text { Qualitative study to answer } \\
\text { two primary research } \\
\text { questions: What are older } \\
\text { adults' perceptions of SNS? } \\
\text { What educational strategies } \\
\text { can facilitate older adults' } \\
\text { learning of SNS? } \\
\text { Weekly semi-structured, } \\
\text { open-ended discussions } \\
\text { were conducted over seven } \\
\text { consecutive weeks to fully } \\
\text { elicit feedback. }\end{array}$ & $\begin{array}{l}\text { Over the course of seven weeks, } \\
\text { participants' perceptions of SNS } \\
\text { transitioned from unanimous, } \\
\text { overwhelmingly negative to a more } \\
\text { positive, engaged perspective. Privacy } \\
\text { was the primary concern. Participants } \\
\text { consistently expressed strong concerns } \\
\text { about protecting personal information on } \\
\text { SNS. }\end{array}$ \\
\hline
\end{tabular}


Table 2. Continued.

\begin{tabular}{|c|c|c|c|c|}
\hline AUTHOR & TYPE & POPULATION & METHOD & MAIN FINDINGS \\
\hline \multicolumn{5}{|c|}{ Studies using questionnaires and interviews } \\
\hline $\begin{array}{l}\text { Shklovski et al. } \\
\text { (2004) }\end{array}$ & JP & $\begin{array}{l}\mathrm{N}=3500 \\
\text { (Follow-up with } \\
\mathrm{N}=1501 \text { ) } \\
\text { Age } 18 \text { or older }\end{array}$ & $\begin{array}{l}\text { Telephone interviews. This } \\
\text { paper uses data from a US } \\
\text { national panel survey } \\
\text { conducted in } 2000 \text { and } \\
2001 \text { to examine the } \\
\text { influence of Internet use on } \\
\text { communication and social } \\
\text { involvement. }\end{array}$ & $\begin{array}{l}\text { The conclusions one can draw from the } \\
\text { cross-sectional and longitudinal (with } \\
\text { follow-up) data differ: the longitudinal } \\
\text { data show that heavy use of the Internet } \\
\text { is associated with reductions in the } \\
\text { likelihood of visiting family or friends on } \\
\text { a randomly selected day. Cross-sectional } \\
\text { analyses show high correlations between } \\
\text { the frequency with which respondents } \\
\text { communicate with specific family } \\
\text { members by visits, phone calls and email, } \\
\text { suggesting that communication in one } \\
\text { medium stimulates the others. }\end{array}$ \\
\hline $\begin{array}{l}\text { Karimi and } \\
\text { Neustaedter } \\
(2010)\end{array}$ & TR & $\begin{array}{l}\mathrm{N}=12 \\
55-59 \text { years } \\
\mathrm{N}=2 \\
60-69 \text { years } \\
\mathrm{N}=6 \\
70-79 \text { years } \\
\mathrm{N}=3 \\
>80 \text { years } \\
\text { (With diverse } \\
\quad \text { living } \\
\text { situations) }\end{array}$ & $\begin{array}{l}\text { Semi-structured interviews } \\
\text { around daily routines and } \\
\text { activities, communication } \\
\text { patterns, and technology } \\
\text { and social media usage. }\end{array}$ & $\begin{array}{l}\text { Variability in both communication } \\
\text { behavior and social media use. Definition } \\
\text { of four archetypes: } \\
\text { - The living newspaper maintains } \\
\text { communication with family and friends } \\
\text { without relying on new technology. } \\
\text { - The high-tech social hub is always online } \\
\text { and available via modern technology. } \\
\text { - The free-spirited bird maintains a } \\
\text { spontaneous lifestyle and prefers not to } \\
\text { have scheduled interactions. } \\
\text { - The isolated communicator makes extra } \\
\text { efforts to maintain communication, but } \\
\text { efforts are not always reciprocated. }\end{array}$ \\
\hline $\begin{array}{l}\text { Chou et al. } \\
\text { (2010) }\end{array}$ & $\mathrm{CP}$ & $\begin{array}{l}\mathrm{N}=60 \\
>55 \text { years } \\
\text { (Internet users) }\end{array}$ & $\begin{array}{l}\text { A questionnaire about } \\
\text { Internet and SNS usage. }\end{array}$ & $\begin{array}{l}\text { The questionnaire revealed the top five } \\
\text { Internet functions most commonly used } \\
\text { by people }>55 \text { years: search data, read } \\
\text { the news, browse Web pages, email, and } \\
\text { online real-time conversation system. } \\
\text { The questionnaire found that } 79 \% \text { of the } \\
\text { participants believe that current Web } \\
\text { design does not take their needs or } \\
\text { preferences into consideration. }\end{array}$ \\
\hline Erickson (2011) & $\mathrm{CP}$ & $\begin{array}{l}\mathrm{N}=7 \\
65-72 \text { years }\end{array}$ & $\begin{array}{l}\text { Telephone interview to assess } \\
\text { the impact of weekly } \\
\text { Facebook use on social } \\
\text { capital. }\end{array}$ & $\begin{array}{l}\text { Main benefit: awareness, knowing what is } \\
\text { going on among family members. } \\
\text { Main concerns: privacy, inappropriate } \\
\text { content. }\end{array}$ \\
\hline $\begin{array}{l}\text { Maier et al. } \\
\quad(2011)\end{array}$ & $\mathrm{CP}$ & $\begin{array}{l}\mathrm{N}=168 \\
50-54 \text { years } \\
\mathrm{N}=93 \\
55-59 \text { years } \\
\mathrm{N}=55 \\
60-64 \text { years } \\
\mathrm{N}=20\end{array}$ & $\begin{array}{l}\text { The aim of this study was to } \\
\text { explain why people do (not) } \\
\text { use particular online } \\
\text { services, even if they have } \\
\text { access to the Internet. An } \\
\text { online survey was conducted } \\
\text { to collect empirical data. }\end{array}$ & $\begin{array}{l}\text { For SNS adopters, a significant impact of } \\
\text { normative beliefs measured as subjective } \\
\text { norm and perceived ease of use could be } \\
\text { observed. However, for non-adopters, } \\
\text { these perceptions had no significant } \\
\text { influence on their intentions for using } \\
\text { SNS. }\end{array}$ \\
\hline
\end{tabular}


Table 2. Continued.

\begin{tabular}{|c|c|c|c|c|}
\hline AUTHOR & TYPE & POPULATION & METHOD & MAIN FINDINGS \\
\hline Barker (2012) & JP & $\begin{array}{l}\mathrm{N}=256 \\
19-29 \text { years } \\
\mathrm{N}=160 \\
41-65 \text { years } \\
\mathrm{N}=96\end{array}$ & $\begin{array}{l}\text { An online survey compared } \\
\text { SNS use among younger } \\
\text { and older subscribers } \\
\text { focusing on the influence of } \\
\text { collective self-esteem and } \\
\text { group identity on motives } \\
\text { for SNS use. }\end{array}$ & $\begin{array}{l}\text { Younger participants reported higher } \\
\text { positive collective self-esteem, social } \\
\text { networking site use for peer } \\
\text { communication, and social } \\
\text { compensation. Regardless of age, } \\
\text { participants reporting high collective } \\
\text { self-esteem and group identity were more } \\
\text { likely to use social networking sites for } \\
\text { peer communication and social identity } \\
\text { gratifications, while those reporting } \\
\text { negative collective self-esteem were more } \\
\text { likely to use social networking sites for } \\
\text { social compensation. }\end{array}$ \\
\hline $\begin{array}{c}\text { Brandtzæg } \\
(2012)\end{array}$ & JP & $\begin{array}{l}\mathrm{N}=2000 \\
61-75 \text { years: } \\
\mathrm{N}=440\end{array}$ & $\begin{array}{l}\text { A representative sample of } \\
\text { Norwegian online users } \\
\text { filled out questionnaires } \\
\text { about SNS use and four } \\
\text { social capital dimensions: } \\
\text { face-to-face interactions, } \\
\text { number of acquaintances, } \\
\text { and bridging capital. The } \\
\text { questionnaires were filled } \\
\text { out annually during } 3 \\
\text { consecutive years (2008, } \\
\text { 2009, and 2010). }\end{array}$ & $\begin{array}{l}\text { This study found a significant higher score } \\
\text { among SNS user in comparison to } \\
\text { non-users in three out of four social } \\
\text { capital dimensions. However, SNS-users } \\
\text { reported more loneliness than non-users. } \\
\text { The findings in this study do not support } \\
\text { claims suggesting that users replace } \\
\text { in-person socializing with SNS. The } \\
\text { results suggest that the usage of SNS and } \\
\text { social contact are supplementary, and } \\
\text { SNS use might extend existing levels of } \\
\text { social contact in all age groups. }\end{array}$ \\
\hline
\end{tabular}

$\mathrm{CP}=$ conference proceedings; JP $=$ journal publication; $\mathrm{N}=$ number of participants; $\mathrm{SNS}=$ social networking sites; $\mathrm{TR}=$ technical report.

SNS use might extend existing levels of social contact in all age groups (Brandtzæg, 2012).

In an online survey with 168 older SNS adopters and non-adopters, Maier and colleagues (2011) found that adopters are influenced by normative beliefs and perceived ease of use. In a questionnaire with 60 Internet users older than 55 years, $79 \%$ of research participants said that current Web design does not take their needs into consideration (Chou et al., 2010). The Internet functions primarily used by this population are "search data," "read the news," "browse Web pages," "email," and "online real-time conversation systems." Another online survey compared SNS use among younger $(\mathrm{N}=$ 160) and older $(\mathrm{N}=96)$ subscribers focusing on the influence of collective self-esteem (Barker, 2012) and revealed that participants reporting high collective self-esteem were more likely to use SNS for peer communication, while those reporting negative collective self-esteem were more likely to use SNS for social compensation.

\section{Discussion}

\section{Motivation of older adults to use social networking sites}

Most of the reviewed articles aimed to better understand the needs of the older SNS users and de- rive requirements for SNS by using questionnaires (Chou et al., 2010; 2012), online surveys (Maier et al., 2011; Barker, 2012; Brandtzæg, 2012), semi-structured interviews (Lehtinen et al., 2009; Karimi and Neustaedter, 2010; Erickson, 2011; Xie et al., 2012), telephone interviews (Shklovski et al., 2004; Erickson, 2011), and focus groups (Richardson et al., 2007; Eggermont et al., 2009; Cornejo et al., 2010; Gibson et al., 2010; Nervik et al., 2011; Norval, 2012; Xie et al., 2012). Researchers have described focus groups as a tool for obtaining information about people's thinking and feelings (Holtzman et al., 2004) and focus groups are an appropriate and well-established technique for preliminary data gathering to obtain insights into a research topic and the needs of a specific group of people (Stoykova et al., 2011). Throughout the reviewed articles, results from focus groups with a total of 35 persons $(\geq 55$ years) and from interviews with 37 persons ( $\geq 55$ years) are surprisingly consistent: privacy issues and fear of inappropriate content were the major barriers to SNS adoption in older users. These findings were confirmed by articles reporting results of questionnaires and online surveys from a total of 288 participants ( $\geq 55$ years). Also, it appeared that the purpose/benefits of SNS are not obvious for older participants (Gibson et al., 2010; 
Maier et al., 2011; Nervik et al., 2011; Norval, 2012).

The lack of obvious purpose and benefit of SNS use might also explain why, in the intervention study of Lehtinen et al. (2009), the older test participants did not adopt SNS. The authors reported that one clear finding of their study was the non-use of SNS by eight participants in the intervention study. The authors hypothesize that none of these participants' acquaintances or friends were using the technology (apart from the other participants in the study). This aligns with the results from focus groups, where the main SNS benefit that older people saw was to "know what is going on among (younger) family members" (Cornejo et al., 2010; Erickson, 2011). Also, Gibson et al. (2010) reported that staying connected with geographically remote grandchildren was a major motivation for older adults in using SNS technology. They concluded that an age-inclusive approach may be more appropriate than an age-exclusive one over the long term. This is supported by the case study of Cornejo and colleagues (2010), who successfully motivated an 88-year-old test participant to adopt Facebook to stay in contact with family members. Success factors are the careful analysis of user needs in focus groups with 15 participants (6597 years) and the consequent user-centered design of two technical systems to integrate the older person into the Facebook SNS: namely a wallmounted electronic picture frame where images that were posted by family members via Facebook and an ambient interface (instrumented balls) that allowed the older person to interact with Facebook without using a desktop computer. The findings will obviously need replication in a larger case control study. Another important finding is that older people have, regardless of their computer experience, a differentiated view to SNS technology (Richardson et al., 2007). Hence, they would like to see SNS to support social relationship, but they also strongly plead for maintenance of face-to-face contacts (Eggermont and Vandebosch, 2009).

\section{Old age-compatible user interfaces to social networking sites}

It is clear that the design requirements for persons older than 85 years differ from those for persons of 56-65 years of age. This difference is not well reflected in the reviewed articles. However, the following general requirements are stated in several reviewed papers: extreme protection of personal information, clear layouts, reduced content, and elimination of extraneous or irrelevant information (Cornejo et al., 2010; Chou et al., 2012). Two groups suggest touchscreens as an appropriate interface technology (Teixeira, 2011; Tsai et al., 2011). This seems to be a good choice because it can simplify the interaction with a computer due to the use of direct eye-hand coordination and by having only one device that serves as input and output (Rowe and Kahn, 1997; Bassuk et al., 1999). Also, ambient interfaces, as proposed by Cornejo et al. (2010), seem to be a promising approach for enhancing interactions of senior citizens with SNS.

\section{Relationship of SNS use to mental health}

There are very few studies assessing the interaction of SNS and mental illness in older people. Several cross-sectional studies report positive impact of "real" social networks on cognitive performance (Bassuk et al., 1999; Seeman et al., 2001; Holtzman et al., 2004; Béland et al., 2005), mental illness (Steffens et al., 2005; Voils et al., 2007; van Beek et al., 2011; van der Post et al., 2012), and quality of life (McLaughlin et al., 2010; Sun et al., 2011; Litwin, 2012). Depression has been directly linked to the subjective sense of loneliness and social isolation (Alpass and Neville, 2003; Ayalon and Shiovitz-Ezra, 2011). In this context, we would expect that enhancing inter-familiar communication via SNS dialogues will have positive impacts on mental health and might help to prevent depression and anxiety. It is clear that the converse argument is not true, i.e. the non-use of SNS will not have per se negative effects on mental health. Under the premise that SNS use increases the size of the social network and intensifies social interaction with existing social contacts, one could expect similar positive effects of SNS use on the cognitive performance and the quality of life of older people. Anecdotic observations from Cornejo and colleagues (2010) support this assumption. However, the relationship between SNS use and real-life communication is not yet clear and findings are reciprocal. Depending on the analysis methodology, Shklovski et al. (2004) found that the Internet and SNS have either positive or negative influence on real-life communication. In young SNS users, studies found a positive relationship between SNS use and the maintenance and creation of social capital (Ellison et al., 2007). One reason for the contradictory findings could be that there are different ways to use SNS and the Internet. As Barker (2012) suggests, some people use the SNS for peer communication while others are more likely to use SNS for social compensation which would explain different implications on other communication forms.

Another study found positive impacts from Facebook use on student motivation, affective learning, and classroom climate (Mazer et al., 2007). Other reports, e.g. Pantic et al. (2012), 
suggest that frequent Facebook use contributes to depression or reduces the time for outdoor physical activity and the time for real social relationships (Lucas et al., 2011). Several studies have mentioned that the use of SNS may contribute to the severity of symptoms associated with Internet addiction and overuse in adolescents and young adults (LaRose et al., 2003; Wilson et al., 2010; Andreassen et al., 2012; Kittinger et al., 2012; Machold et al., 2012). However, whether the findings for young cohorts can be transferred to older adults needs to be assessed in future studies, and the risks and potential benefits of SNS to prevent or treat mental illness in older people will clearly need more attention in the future.

Older users and SNS is an interdisciplinary topic and a strength of this review is that it summarizes and interprets literature from different fields, including medical, technical, psychological, gerontological, and communication sciences. An important limitation is that the number of studies that could be included in this review is rather small and that many studies are of qualitative nature with a small number of participants. Nevertheless, it reflects the state of research, the novelty of the topic, and emphasizes the need for more investigations in this field.

\section{Conclusions and future research directions}

SNS are an important way of communication for younger generations. They allow individuals to connect with others, regardless of location, creating more opportunities to share topics of interest, interact with others, and provide emotional and moral support, as well as stay in touch with family and friends (Erickson, 2011). As such, SNS add to the diversity of communication and may also represent new avenues for maintaining and strengthening key relationships for the growing population of aging adults (Béland et al., 2005). Particularly for older people with limited mobility, SNS may help maintain connections that would otherwise be difficult or impossible to preserve (Erickson, 2011). There is evidence that SNS might enable them to stay in touch with younger generations and that this intergenerational interaction is very beneficial for and appreciated by both sides (Cornejo et al., 2010). These findings are also supported from studies investigating SNS use in people with traumatic brain injury (Tsaousides et al., 2011) and stroke (Mittal et al., 2012). Under these premises, it is hard to understand why current popular SNS fail to take the needs of older people into consideration and why $79 \%$ of older SNS users realize that current Web design does not factor in their needs (Chou et al., 2010). There are a number of SNS that are specifically developed for older people (Farkas, 2010). However, the ageexclusive approach with different SNS for different age groups will probably not be successful, because the interaction with younger family members is one of the major drivers for senior citizens to use SNS.

With respect to the importance of the topic, there are few articles reporting results of experiments with older people that are exposed to SNS. There is a clear need for more studies that observe older people when using SNS (Lehtinen et al., 2009; Chou et al., 2012). As mentioned before, special attention should be directed to assess possible negative side effects (e.g. addiction and less physical activities). Also, experimental studies with ambient interfaces (Cornejo et al., 2010) that enable the very old ( $>85$ years) to use SNS without requiring a desktop computer are promising and of great interest. Besides usage information, it would also be important to measure the influence of SNS usage on mental health and on the inter-family and intergenerational communication behavior. Also, gender differences and possible gender biases should be addressed in future studies.

Most SNS (e.g. Facebook) were developed for university students and thus they are likely to reflect the norms about public and private life held by young adults and adolescents. Studies reporting results from focus-group meetings with older users consistently reported that these norms (e.g. privacy and purpose) differ for younger and older cohort (Subrahmanyam et al., 2008; Gibson et al., 2010; Chou et al., 2012; Norval, 2012). These differences are an excellent site for future research. Moreover, studies such as Chou et al. (2010) and Nervik et al. (2011) looking at what older adults are actually doing when using the Internet (i.e. e-mail, online real-time conversation, and SNS) are important to better understand the implications of the differences between older and younger users.

\section{Conflict of interest}

None.

\section{Description of authors' roles}

All authors devised the review protocol and study inclusion criteria, and analyzed the study findings. Tobias Nef and Raluca Ganea conducted the literature searches, data extraction, and resolved any disagreements in the latter with René Müri and Urs Mosimann. All authors took part in writing and approving the paper.

\section{Acknowledgments}

This study has been financed in parts by the AAL Joint Program (FP7) through the proposal 
Safemove - Safe mobility of elderly in the vicinity of their home and on journeys.

\section{Disclaimer}

The authors have no direct or indirect financial interest in social networking sites.

\section{References}

Alpass, F. M. and Neville, S. (2003). Loneliness, health and depression in older males. Aging and Mental Health, 7, 212-216. doi:10.1080/1360786031000101193.

Andreassen, C. S., Torsheim, T., Brunborg, G. S. and Pallesen, S. (2012). Development of a Facebook Addiction Scale. Psychological Reports, 110, 501-517. doi: 10.2466/02.09.18.PR0.110.2.501-517.

Ayalon, L. and Shiovitz-Ezra, S. (2011). The relationship between loneliness and passive death wishes in the second half of life. International Psychogeriatrics, 1, 1-9. doi:10.1017/S1041610211001384.

Barker, V. (2012). A generational comparison of social networking site use: the influence of age and social identity. International fournal of Aging and Human Development, 74, 163-187. doi:10.2190/AG.74.2.d.

Bassuk, S. S., Glass, T. A. and Berkman, L. F. (1999). Social disengagement and incident cognitive decline in community-dwelling elderly persons. Annals of internal medicine, 131, 165-173.

Béland, F., Zunzunegui, M. V., Alvarado, B., Otero, A. and Del Ser, T. (2005). Trajectories of cognitive decline and social relations. The fournals of Gerontology Series B: Psychological Sciences and Social Sciences, 60, 320-330. doi:10.1093/geronb/60.6.P320.

Brandtzæg, P. B. (2012). Social networking sites: their users and social implications - a longitudinal study. Fournal of Computer-Mediated Communication, 17, 467-488. doi: $10.1111 /$ j.1083-6101.2012.01580.x.

Chou, W. H., Lai, Y. T. and Liu, K. H. (2010). Decent Digital Social Media for Senior Life: A Practical Design Approach. In 3rd IEEE International Conference on Computer Science and Information Technology (ICCSIT), (pp. 249-253). IEEE.

Chou, W. H., Lai, Y. T. and Liu, K. H. (2012). User requirements of social media for the elderly: a case study in Taiwan. Behaviour and Information Technology, 1-18, iFirst Article. doi:10.1080/0144929X.2012.681068.

Cornejo, R., Favela, J. and Tentori, M. (2010). Ambient displays for integrating older adults into social networking sites. Collaboration and Technology, 321-336.

Eggermont, S. and Vandebosch, H. (2009). Towards the desired future of elderly and ICT: policy recommendations based on a dialogue with senior citizens. Paper presented at the annual meeting of the International Communication Association, Sheraton New York, New York City, NY. doi:10.1007/s10202-005-0017-9.

Ellison, N. B. (2007). Social network sites: definition, history, and scholarship. Fournal of Computer-Mediated Communication, 13, 210-230. doi:10.1111/ j.1083-6101.2007.00393.x.
Ellison, N. B., Steinfield, C. and Lampe, C. (2007). The benefits of Facebook "friends": social capital and college students' use of online social network sites. Fournal of Computer-Mediated Communication, 12, 1143-1168. doi:10.1111/j.1083-6101.2007.00367.x.

Erickson, L. B. (2011). Social Media, Social Capital, and Seniors: The Impact of Facebook on Bonding and Bridging Social Capital of Individuals over 65. AMCIS 2011 Proceedings - All Submissions, Paper 85.

Farkas, P. A. (2010). Senior Social Platform - An Application Aimed to Reduce the Social and Digital Isolation of Seniors. In Proceedings of REAL CORP, Vienna.

Fees, B. S. and Bradshaw, M. H. (2003). PATH across the generations: older adults' perceptions on the value of intergenerational contact. Care Management fournals, 4, 209-215.

Gibson, L. et al. (2010). Designing social networking sites for older adults. In Proceeding BCS '10 of the 24th BCS Interaction Specialist Group Conference, British Computer Society, Swinton, UK, 186-194.

Giles, H., Hajek, C., Stoitsova, T. and Choi, C. W. (2010). Intergenerational communication satisfaction and age boundaries in Bulgaria and the United States. Fournal of Cross-Cultural Gerontology, 25, 133-147. doi:10.1007/s10823-010-9114-x.

Harwood, J. (2007). Understanding Communication and Aging: Developing Knowledge and Awareness (344 pp.). Thousand Oaks, CA: SAGE. doi:10.4135/9781452225920.

Holtzman, R. E. et al. (2004). Social network characteristics and cognition in middle-aged and older adults. The fournals of Gerontology Series B: Psychological Sciences and Social Sciences, 59, 278-284. doi:10.1093/geronb/59.6.P278.

Johnson, J. (2012). Social Networks Broken Down by Demographic. The Blog Herald. Available at: http://www.blogherald.com/2012/06/07/social-networksbroken-down-by-demographic-infographic/.

Joinson, A. N. (2008). Looking at, Looking up or Keeping up with People? Motives and Use of Facebook (pp. 1027-1036). In Proceedings of ACM CHI 2008 Conference on Human Factors in Computing Systems. New York: ACM. doi: 10.1145/1357054.1357213.

Jones, S., Fox, S., Internet, P. and Project, A. L. (2009). Generations Online in 2009. Washington, DC: Pew Internet \& American Life Project.

Karimi, A. and Neustaedter, C. (2010). My Grandma Uses Facebook: Communication Practices of Older Adults in an Age of Social Media.

Katz, J. E. and Aspden, P. (1997). A nation of strangers? Communications of the ACM, 40, 81-86. doi:10.1145/265563.265575.

Kittinger, R., Correia, C. J. and Irons, J. G. (2012). Relationship between Facebook use and problematic Internet use among college students. Cyberpsychology, Behavior, and Social Networking, 15, 324-327. doi:10.1089/cyber.2010.0410.

Kraut, R., Kiesler, S., Boneva, B., Cummings, J., Helgeson, V. and Crawford, A. (2002). Internet paradox revisited. Fournal of social issues, 58, 49-74. doi:10.1111/1540-4560.00248.

Kraut, R., Patterson, M., Lundmark, V., Kiesler, S., Mukophdyay, T. and Scherlis, W. (1998). Internet paradox: a social technology that reduces social 
involvement and psychological well-being? American psychologist, 53, 1017. doi:10.1037/0003-066X.53.9.1017.

Kueider, A. M., Parisi, J. M., Gross, A. L. and Rebok, G. W. (2012). Computerized cognitive training with older adults: a systematic review. PLoS One, 7, e40588. doi:10.1371/journal.pone.0040588.

LaRose, R., Lin, C. A. and Eastin, M. S. (2003). Unregulated Internet usage: addiction, habit, or deficient self-regulation? Media Psychology, 5, 225-253. doi:10.1207/S1532785XMEP0503_01.

Lehtinen, V., Näsänen, J. and Sarvas, R. (2009). A little silly and empty-headed: older adults' understandings of social networking sites. In Proceeding of the 2009 British Computer Society Conference on Human-Computer Interaction, BCS-HCI 2009, Cambridge, United Kingdom, pp. 45-54.

Litwin, H. (2012). Physical activity, social network type, and depressive symptoms in late life: an analysis of data from the national social life, health and aging project. Aging and Mental Health, 16, 608-616. doi:10.1080/ 13607863.2011 .644264$.

Lovett, G. (2011). Over 50s drive facebook growth. Marketing Week. Available at: http://www.marketingweek.co.uk/over50s-drive-facebook-growth-study-says/3027863.article.

Lucas, M. et al. (2011). Relation between clinical depression risk and physical activity and time spent watching television in older women: a 10-year prospective follow-up study. American fournal of Epidemiology, 174, 1017-1027. doi:10.1093/aje/kwr218.

Machold, C. et al. (2012). Social networking patterns/hazards among teenagers. Irish Medical fournal, 105, 151-152.

Maier, C., Laumer, S. and Eckhardt, A. (2011). Technology adoption by elderly people-an empirical analysis of adopters and non-adopters of social networking sites. Wirtschaftsinformatik Proceedings 2011, Paper 25.

Mazer, J. P., Murphy, R. E. and Simonds, C. J. (2007). I'll see you on "Facebook": the effects of computer-mediated teacher self-disclosure on student motivation, affective learning, and classroom climate. Communication Education, 56, 1-17. doi:10.1080/03634520601009710.

McKenna, K. Y., Green, A. S. and Gleason, M. E. (2002). Relationship formation on the Internet: what's the big attraction? Fournal of social Issues, 58, 9-31. doi:10.1111/1540-4560.00246.

McLaughlin, D., Vagenas, D., Pachana, N. A., Begum, N. and Dobson, A. (2010). Gender differences in social network size and satisfaction in adults in their 70s. Fournal of Health Psychology, 15, 671-679. doi:10.1177/ 1359105310368177.

Mesch, G. S. (2012). Technology and youth. New Directions for Youth Development, 2012, 97-105. doi:10.1002/yd.20032.

Mittal, M. K., Sloan, J. A. and Rabinstein, A. A. (2012). Facebook: can it be a diagnostic tool for neurologists? BMF Case Reports, 2012. doi:10.1136/bcr-2012-006426.

Moher, D., Liberati, A., Tetzlaff, J. and Altman, D. G. (2009). Preferred reporting items for systematic reviews and meta-analyses: the prisma statement. PLoS Med, 6, e1000097.

Nervik, T., Dahl, Y. and Kofod-Petersen, A. (2011). The Value of Role Models in Design of Social Media for Elderly. Presented at 23rd International Conference of the
European Federation for Medical Informatics, Oslo, Norway.

Nie, N. H., Hillygus, D. S. and Erbring, L. (2002). Internet use, interpersonal relations, and sociability. In: B. Wellman and C. Haythornthwaite (Eds.), The Internet in Everyday Life, pp. 213-243. Oxford: Blackwell Publishers. doi:10.1002/9780470774298.ch7.

Norval, C. (2012). Understanding the incentives of older adults' participation on social networking sites. $A C M$ SIGACCESS Accessibility and Computing, 102, 25-29. doi:10.1145/2140446.2140452.

Nussbaum, J. F. and Coupland, J. (2004). Handbook of Communication and Aging Research. Hillsdale, NJ: Lawrence Erlbaum. doi:10.1207/s15327027hc0804_4.

Pantic, I. et al. (2012). Association between online social networking and depression in high school students: behavioral physiology viewpoint. Psychiatria Danubina, 24, 90-93.

Richardson, M., Zorn, T. and Weaver, C. K. (2007). Not "getting-on": older non-users' meanings for computers. Paper Presented at the Annual Meeting of the International Communication Association, TBA, San Francisco, CA, 23 May 2007.

Rowe, J. W. and Kahn, R. L. (1997). Successful aging. The Gerontologist, 37, 433-440.

Seeman, T. E., Lusignolo, T. M., Albert, M. and Berkman, L. (2001). Social relationships, social support, and patterns of cognitive aging in healthy, high-functioning older adults: Macarthur studies of successful aging. Health Psychology, 20, 243-255. doi:10.1037/0278-6133.20.4.243.

Shklovski, I., Kraut, R. and Rainie, L. (2004). The Internet and social participation: contrasting cross-sectional and longitudinal analyses. Fournal of Computer-Mediated Communication, 10. doi: $10.1111 /$ j.1083-6101.2004.tb00226.x.

Steffens, D. C. et al. (2005). Biological and social predictors of long-term geriatric depression outcome. International Psychogeriatrics, 17, 41-56. doi:10.1017/ S1041610205000979.

Stoykova, R., Matharan, F., Dartigues, J. F. and Amieva, H. (2011). Impact of social network on cognitive performances and age-related cognitive decline across a 20-year follow-up. International Psychogeriatrics, 1, 1-8. doi:10.1017/S1041610211001165.

Subrahmanyam, K., Reich, S. M., Waechter, N. and Espinoza, G. (2008). Online and offline social networks: use of social networking sites by emerging adults. Fournal of Applied Developmental Psychology, 29, 420-433. doi:10.1016/j.appdev.2008.07.003.

Sun, X., Lucas, H., Meng, Q. and Zhang, Y. (2011). Associations between living arrangements and health-related quality of life of urban elderly people: a study from China. Quality of Life Research, 20, 359-369. doi:10.1007/s11136-010-9752-z.

Teixeira, V. (2011). Improving Elderly Access to Audiovisual and Social Media, Using a Multimodal Human-Computer Interface. Porto, Portugal: Faculdade de Engenharia, Universidade do Porto.

Tsai, T. and Chang, H. (2009). Sharetouch: a multi-touch social platform for the elderly. 11th IEEE International Conference on Computer-Aided Design and Computer Graphics, 2009 (pp. 557-560). IEEE 
Tsai, T. H., Chang, H. T., Wong, A. and Wu, T. F. (2011). Connecting communities: designing a social media platform for older adults living in a senior village. Universal Access in Human-Computer Interaction. Users Diversity, 6766 224-233.

Tsaousides, T., Matsuzawa, Y. and Lebowitz, M. (2011). Familiarity and prevalence of Facebook use for social networking among individuals with traumatic brain injury. Brain Injury, 25, 1155-1162. doi:10.3109/ 02699052.2011 .613086$.

Turkle, S. (1997). Life on the Screen: Identity in the Age of the Internet. Simon and Schuster. doi:10.1207/ s15327965pli0604_5.

van Beek, A. P., Frijters, D. H., Wagner, C., Groenewegen, P. P. and Ribbe, M. W. (2011). Social engagement and depressive symptoms of elderly residents with dementia: a cross-sectional study of 37 long-term care units. International Psychogeriatrics, 23, 625-633. doi:10.1017/S1041610210002061.

van der Post, L. F. et al. (2012). Social support and risk of compulsory admission: part IV of the Amsterdam study of acute psychiatry. Psychiatric Services, 63, 577-583. doi:10.1176/appi.ps.201100080.

Voils, C. I. et al. (2007). Five-year trajectories of social networks and social support in older adults with major depression. International Psychogeriatrics, 19, 1110-1124. doi:10.1017/S1041610207005303.
Wellman, B., Haase, A. Q., Witte, J. and Hampton, K. (2001). Does the Internet increase, decrease, or supplement social capital? Social networks, participation, and community commitment. American Behavioral Scientist, 45, 436-455. doi:10.1177/ 00027640121957286.

Wilson, K., Fornasier, S. and White, K. M. (2010). Psychological predictors of young adults' use of social networking sites. Cyberpsychology Behavior and Social Networking, 13, 173-177.

Williams, A. and Nussbaum, J. F. (2001). Intergenerational Communication Across the Life Span. New Jersy: Lawrence Erlbaum.

Williams, K., Kemper, S. and Hummert, M. L. (2005). Enhancing communication with older adults: overcoming elderspeak. Fournal of Psychosocial Nursing and Mental Health Services, 43, 12-16.

Wire, N. (2010). Social Networks/Blogs Now Account for One in Every Four and a Half Minutes Online. Nielson Wire. Available at: http://www.nielsen.com/us/en/newswire/ 2010/social-media-accounts-for-22-percent-of-timeonline.html.

Xie, B., Watkins, I., Golbeck, J. and Huang, M. (2012). Understanding and changing older adults' perceptions and learning of social media. Educational Gerontology, 38, 282-296. 